Філологія

UDC 811.111'373.23(73)

Bahlai Marta

Student of Philology of the Department of Applied Linguistics Institute of Computer Science and Information Technology of Lviv Polytechnic National University

Karp Marta PhD in Philology, Assistant Professor of Department of Applied Linguistics Institute of Computer Science and Information Technology of Lviv Polytechnic National University

\title{
TROPES IN POLITICAL SPEECHES BY CONDOLEEZZA RICE
}

Summary. The research is focused on the political speeches and their features. The article reviews lexico-semantic stylistic devices and expressive means in the political speeches of US Secretary of State Condoleezza Rice and their influence on the consciousness of the audience.

Key words: Condoleezza Rice, political discourse, political speeches, stylistic devices, tropes.

Statement of the problem. Political activity has always played a special role in the life of society. The country place in the international arena, its relationship with other states, its role in the activities of the world community depend on a certain political position or situation. However, an important role in determining the image of the country plays the way of its presentation by the political leaders of this state. With the help of speeches, politicians have the opportunity to address both the international community and the citizens of their 
country. This problem requires a thorough study since political speeches has the influence on the consciousness of the audience.

Analysis of recent research and publications. Analysing political discourse in the global communicative space, E.K. Pavlova regards political discourse as a public discourse based on the political picture of the world, aimed at its formation, change, and use in order to motivate people to one or another social activity [10, p.16]. Political discourse takes up a large portion of public speech with the purpose of presenting facts, opinions, and attitudes of speakers towards a particular subject $[1, \mathrm{p} .4]$.

The aim of the article deals with examining and exposing lexico-semantic stylistic devices in Condoleezza Rice's speeches and pointing out examples of linguistic strategies that impose moral and ethical values on listeners.

Presentation of the main material. One of the most important aspects of rhetoric is a speech - a public speaking on a particular occasion, with a clear structure, meaning and purpose. Political speech is one of the key mechanisms of impact on the audience, as well as the most powerful tool for informing and convincing a large group of people. A speech can be defined as a political one if it corresponds to several characteristics. Firstly, the political text is part of the political activities of parties, individual politicians, political and nongovernmental organisations. Secondly, their feature concerns the focus on the general public.

In political speeches during election campaigns, ideas and ideologies need to be conveyed through language so that they are agreed upon by the receivers as well as by others who may read or hear parts of the speech afterwards in the media. Words and expressions are used or omitted to affect meaning in different ways. Moreover, political speeches are composed by a team of professional speech writers, who are educated in the use of persuasive language. Adding stylistic devices to a pre-composed speech may be of crucial importance to election results. 
A political speech is not necessarily a success because of correctness or truth, rather it may be a matter of presenting valid arguments [2, p. 18].

An important feature of political speech is its interactional nature; it is aimed not so much at expression, but at persuasion. Thus, according to S. Ivanova, "public speech is a monologue in its form and a dialogue in its essence. The degree of availability of characteristics of a lively conversation determines the level of impact on the audience" [9, p. 7]. "A public speech, like any other kind of a genre, involves two participants of the communication situation; it actually tries to avoid unilateralism, wants to be bilateral, interactional and escapes monologue" $[8, \mathrm{p}$. 9]. A talented politician is able to enter into a dialogue with all strata of the society. According to O. Sheyhal, an interactional character of a democratic political discourse lies in its fundamental polemical nature. A polemical nature is implemented in pragmatic principles of cooperation and competition [11, p. 61]. Thus, the political speech that exerts an impact on the recipient is co-produced by the addresser with the addressee.

After analysing political discourse features we may assume that in speeches of Condoleezza Rice is a great number of stylistic units. For our research, we have chosen two speeches of Condoleezza Rice: campaign speech in US Department of State (January 19, 2006), solemn speech in Georgetown University (January 18, 2006). Such stylistic devices as metaphor, personification, euphemism, enumeration, repetition and polysyndeton have been determined.

Metaphor is a highly used rhetorical tool in political discourse. It has the powerful ability to influence our thoughts and perception. That is why metaphor is an indispensable and frequently applied figure of Condoleezza Rice's speeches: "We must train record numbers of people to master difficult languages like Arabic and Chinese and Farsi and Urdu" [6]. In this example we can see that a well-chosen metaphorical expression helps to create an image of a large number of people. Impression is positive after this metaphor as it is about promoting a record number of people in the study of foreign languages, but, for 
example, this metaphor "a diplomatic force" in the sentence "It is clear today that America must begin to reposition our diplomatic forces around the world, so over the next few years the United States will begin to shift several hundred of our diplomatic positions to new critical posts for the 21 st century" [6] is alarming, i.e. although it refers to diplomacy, the word force has a military background and is associated primarily with war and violence.

The metaphor "the most ambitious development agenda" in the sentence "Under President Bush's leadership, the United States has embarked on the most ambitious development agenda since the Marshall Plan" [6] gives a qualitative characteristics of the United States' plans for the implementation of their diplomacy in the world.

In the sentence "It was also assumed that weak and poorly governed states were merely a burden to their people, or at most, an international humanitarian concern but never a true security threat' [6] Condoleezza Rice makes an effort to bring power closer to ordinary citizens and to show that all actions of politicians are aimed at welfare of citizens.

The metaphor "distant corners of the earth" is used in the sentence "The people of USAID are bringing essential knowledge and recourses and skills to distant corners of the earth" [3] to show that knowledge, recourses and skills were delivered to many different parts of the world.

In her speeches Condoleezza Rice uses metaphors that are democratic and have the appeals for combating communism and protect freedom as one of the key concepts among the values of the American people. For example: “Our diplomacy was instrumental in transforming devastated countries into thriving democratic allies, allies who joined with us for decades in the struggle to defend freedom from communism."; "And the United States is working with our many partners, particularly our partners who share our values in Europe and in Asia and in other parts of the world to build a true form of global stability, a balance of power that favors freedom."; "And 
we are joining with key regional countries like Indonesia and Nigeria and Morocco and Pakistan, working together not only to take the fight to the enemy but also to combat the ideology of hatred that uses terror as a weapon."; "I've seen the noble spirit of that service, a service that defines the men and women of our Foreign Service and Civil Service and our Foreign Service Nationals, many of whom are serving in dangerous places far away from their families." [6].

The following metaphors are used to show voters the availability of alternatives. For example, in Condoleezza Rice's speeches: “We are making these changes by shifting existing resources to meet our new priorities, but we are also eager to work more closely with Congress to enhance our global strategy with new resources and new positions."; "In the 21st century, emerging nations like India and China and Brazil and Egypt and Indonesia and South Africa are increasingly shaping the course of history."; "In this world it is impossible to draw neat, clear lines between our security interests, our development efforts and our democratic ideals." [6]. These metaphors create the notion that the future of the state is always in the hands of its citizens, and that their conscious choice helps in establishing democratic ideals and principles that will be the key to the success of their homeland.

Furthermore, in the Condoleezza Rice's speeches, the medical vocabulary is used to denote political phenomena: "It [reform] will enhance accountability from both the donors and the recipients of assistance." [6] In this example the "donors" mean the people (the country) that provide the help, and the "recipients" are the people who receive it.

It is not a rare phenomenon the usage of economic and financial vocabulary in metaphorical terms: "I also want you to know that I do know a good deal about Georgetown and it is because this is a fine school of foreign service for which we all owe a debt of gratitude for the people that you have 
trained."; "Our efforts helped newly liberated peoples to transform the character of their countries and now many of them, too, have become partners in liberty and freedom, members of NATO, members of the European Union, something unthought of just a few years ago.", "Most importantly, Secretary Powell invested in our people." [6]

Personification, i.e. a thing - an idea or an animal - is given human attributes [5], has been used in speeches by Condoleezza Rice: “Over the past 15 years, as violent state failure has become a greater global threat, our military has born a disproportionate share of post-conflict responsibilities because we have not had the standing civilian capability to play our part fully." [6], where "has born" means "to create, to cause".

A euphemism is a polite expression used in place of words or phrases that might otherwise be considered harsh or unpleasant [4]. Euphemies have been used in the political speeches of Condoleezza Rice, in particular, in its system of division of countries. Countries like Iraq, Afghanistan and Angola, that is, the country where the anti-democratic regime prevails, she calls "critical" or "failed countries". To "critical countries", Condoleezza Rice has also ranked China, India, South Africa and Indonesia. For example: "These are challenging jobs in critical countries like Iraq and Afghanistan and Sudan and Angola, countries where we are working with foreign citizens in difficult conditions to maintain security and fight poverty and make democratic reforms." [6] In contrast to "critical countries", she has identified other types of countries - "transitional countries" (some countries of Africa, Latin America and the Middle East) and "key regional countries" (Nigeria, Morocco, Pakistan). For instance: "And we are joining with key regional countries like Indonesia and Nigeria and Morocco and Pakistan, working together not only to take the fight to the enemy but also to combat the ideology of hatred that uses terror as a weapon." [6]. The phrase "men and women in uniform" in the sentence "So to advance transformational diplomacy we are 
empowering our diplomats to work more jointly with our men and women in uniform." [6] implies designation of military force. Such phrase does not cause disturbing perception, since it is more "peaceful".

Enumeration is a stylistic device by which separate things, objects, phenomena, properties, actions are named one by one so that they produce a chain [7]. For example, in her political speech, Condoleezza Rice says: "We seek to use America's diplomatic power to help foreign citizens to better their own lives and to build their own nations and to transform their own futures." [3]. In this statement one of the enumeration thematic series is used, moreover, with the deliberate repetition of the infinitive construction To + Verb + Possessive Pronoun + Noun. This construction of the sentence is aimed at influencing the emotional state of the individual and his patriotic feelings.

Repetition is recurrence of the same word, word combination or phrase two or more times. Skillfully used and justified repetition never creates the redundancy of information. It is powerful means of emphasis, besides it adds rhythm and balance to the utterance [7]. Condoleezza Rice uses in her speeches such types of repetition as anaphora, successive and catch repetition.

Anaphora is the repetition of elements at the beginning of each consecutive syntactic structure [7]. In the Condoleezza Rice's speeches, we see the following examples of the use of anaphora: "We are forward deploying our people to the cities and countries and regions where they are needed most. We are moving our diplomats from Europe and Washington to critical countries like China and India and South Africa and Indonesia. We are giving more of our people new training and language skills to engage directly with foreign peoples." [3]. In this example, we have observed the repetition of the phrase "we are" at the beginning of each sentence. Such a repetition helps to focus the attention of the listener on the subject in the sentence, that is, the performer of action, and therefore serves as an additional means of persuasion. 
Condoleezza Rice begins every part of the complex sentence with the repetition of the word "democracy" in "Ladies and gentlemen, America has come a long way and America stands as a symbol but also a reality for all of those who have a long way to go, that democracy is hard and democracy takes time, but democracy is always worth it." [6] aimed at the emotional impact on the listener, since she draws attention to the patriotic feelings and values of the American people.

Successive repetition is a string of closely following each other reiterated units. This is the most emphatic type of repetition, which signifies the peak of speaker's emotions, or imparts the greatest logical significance to the repeated element [7]. In her speeches, Condoleezza Rice uses the following examples of consecutive repetitions: "With that, and with the hopes for a more effective, a more effective foreign assistance program, but one that speaks to America's true values of the promotion of democracy and good governance." [3]. Using the repeated phrase "a more effective", the author tries to convince the listener of the importance of the new United States policy.

In catch repetition (anadiplosis) the end of one clause or sentence is repeated at the beginning of the following one. Such a stylistic device indicates the connection between the two ideas, increases not only expressiveness, but also rhythm [7]. In Condoleezza Rice's political speeches, we can find the following examples of catch repetition: "To achieve this bold mission, America needs equally bold diplomacy, a diplomacy that not only reports about the world as it is, but seeks to change the world itself." [6]. In the above-mentioned example, due to the catch repetition, we have noticed an attempt to draw the attention of the listener to the word "diplomacy", and make him realise the importance of the goal, the importance of the new United States policy.

In this example, "Our diplomacy was instrumental in transforming devastated countries into thriving democratic allies, allies who joined with us for decades in the struggle to defend freedom from communism." [6] 
Condoleezza Rice repeats the word "allies", expressing respect and gratitude to those countries that will join the new transformational policy of the United States, stressing that they will become allies in one common cause.

Polysyndeton is stylistically motivated deliberate repetition of conjunctions or prepositions [7]. In the speeches of Condoleezza Rice, we have found the following examples of polysyndeton: "We seek to use America's diplomatic power to help foreign citizens better their own lives and to build their own nations and to transform their own futures." [3]; "We are forward deploying our people to the cities and countries and regions where they are needed most." [3]; "The people of USAID are bringing essential knowledge and resources and skills to distant corners of the earth." [3]. In the above-mentioned examples, the conjunction "and" functions as polysyndeton. The use of this conjunction helps the reader to understand that all components of the sentence are equally important and bear the same semantic load. In addition, the use of this polysyndeton makes the sentence rhythmic, and therefore easier to perceive information.

Conclusion. Exploring the political speeches of US Secretary of State Condoleezza Rice, we have come to the conclusion that a political speech is a public statement aimed at influencing public consciousness. There are certain lexico-semantic stylistic devices that help the speaker with influencing, e.g. metaphor, personification, euphemism, enumeration, repetition and polysyndeton. A political promise can heavily influence the audience and its responses, yet stylistic devices help in conveying messages. A positive response can lead to electoral success, thus studies concerning the use of stylistic devices and the frequency of their occurrence help to assess the relationship between audience responses and political victory. 


\section{References}

1. Alexiyevets O. Prosody of the viewpoint in political discourse. Lege artis. Language yesterday, today, tomorrow / Oxana Alexiyevets. // The Journal of University of SS Cyril and Methodius in Trnava. Warsaw: De Gruyter Open. 2017. P. 4-41.

2. Beard A. The Language of Politics / Adrian Beard. London: Routledge, 2000. $136 \mathrm{p}$.

3. Campaign speech in U.S Department of State. URL: https://20012009.state.gov/secretary/rm/2006/59408.htm.

4. Examples of euphemism. URL: https://examples.yourdictionary.com/examples-of-euphemism.html.

5. Personification definition. URL: https://iterarydevices.net/personification/.

6. Solemn speech in Georgetown University. URL:https://20012009.state.gov/secretary/rm/2006/59306.htm.

7. Syntactic stylistic devices based on the extension of sentence model. URL: https://studfile.net/preview/5199544/page:3/.

8. Данилина В. В. Ритмический анализ политической публичной речи / Варвара Викторовна Данилина. Москва: Флинта: Наука, 2004. 240 с.

9. Иванова С. Ф. Специфика публичной речи / Софья Филипповна Иванова. Москва: Знание, 1978. 72 с.

10. Павлова Е. К. Политический дискурс в глобальном коммуникативном пространстве / Елена Касимовна Павлова. Москва, 2010. 45 с.

11. Шейгал Е. И. Семиотика политического дискурса / Елена Иосифовна Шейгал. Волгоград: Перемена, 2000. 368 с. 